\title{
ANALISIS USAHA TERNAK AYAM BROILER (STUDI KASUS DI TERNAK AYAM KUNTO DEWO DUSUN DAMAR DESA SEKARMOJO)
}

\author{
Mokh. Maghrobil Muhibbin ${ }^{1}$, Idah Lumhatul Fuad ${ }^{2}$ \\ ${ }^{1}$ Mahasiswa Program Studi Agribisnis, Universitas Yudharta Pasuruan. \\ ${ }^{2}$ Dosen Program Studi Agribisnis, Universitas Yudharta Pasuruan. \\ Email: ilumfuad@yudharta.ac.id
}

\begin{abstract}
ABSTRAK
Usaha peternakan ayam broiler Kunto Dewo memiliki kapasitas ayam 14.000 ekor ayam per periode produksi. Peternakan tersebut bergabung dengan kemitraan PT Sinar Sarana Sentosa. Pada sistem kemitraannya, peternakan Kunto Dewo mendapat sistem harga kontrak tetap penjualan ayam. Harga itu menghindarkan peternakan Kunto Dewo dari penurunan penerimaan akibat jatuhnya harga di pasar tetapi juga menyebabkan penerimaan tetap.Penelitian ini bertujuan untuk mengetahui sistem produksi usaha peternakan ayam broiler, biaya produksi, penerimaan dan pendapatan bersih usaha, dan analisis efisiensi usahatani peternakan ayam broiler di ternak ayam Kunto Dewo. Metode penelitian yang digunakan adalah kuantitatif. Data kuantitatif dikumpulkan dan diolah kemudian dijelaskan secara deskriptif dan selanjutnya disajikan menggunakan model analisis efisiensi. Hasil penelitian menunjukkan sistem produksi usaha ayam broiler di peternakan Kunto Dewo meliputi empat tahap yaitu persiapan kandang, pemberian pakan dan minum, pencatatan, dan tahap terakhir proses pemanenan. Untuk Biaya produksi pada peternakan ayam broiler Kunto Dewo sebesar $\mathrm{Rp}$ 422,526,612. Sedangkan total penerimaan sebesar $\mathrm{Rp}$ 438,641,400. Hasil perhitungan BEP penerimaan sebesar Rp. 114.536.532,26. untuk nilai BEP produksi sebesar 6.865,43 Kg, sedangkan nilai BEP harga Rp 16.251,02/Kg, dan Nilai BEP luas sebesar 2416,1 m2. Perhitungan laba rugi peternakan Kunto Dewo mengalami keuntungan karena nilai penerimaan, hasil produksi, harga jual ayam, dan luas melebihi nilai perhitungan BEP. Sedangkan untuk nilai R/C Ratio sebesar 1.038 yang artinya bahwa usaha peternakan Kunto Dewo mendapatkan keuntungan karena nilai $\mathrm{R} / \mathrm{C}$ ratio > 1. untuk hasil perhitungan B/C Ratio sebesar 3,813 yang artinya bahwa usaha peternakan Kunto Dewo berdasarkan hasil perhitungan B/C Ratio dikatakan tidak layak karena nilai B/C Ratio < dari bunga bank yang berlaku, bunga bank yang berlaku saat ini adalah 4,50\%.

Kata kunci: Usaha, Peternakan Ayam Broiler.
\end{abstract}

\section{ABSTRACT}

The Kunto Dewo broiler chicken farm has a capacity of 14,000 chickens per production period. The farm joined the partnership of PT Sinar Sarana Sentosa. In the partnership system, Kunto Dewo farm gets a fixed contract price system for chicken sales. The price avoids Kunto Dewo farms from decreasing revenue due to falling prices on the market but also causes fixed income. This study aims to determine broiler farming production systems, production costs, revenues and business income, and efficiency analysis of broiler farms in livestock Kunto Dewo chicken. The research method used is quantitative. Quantitative data is collected and processed then explained descriptively and then presented using an efficiency analysis model. The results showed that the production system of broiler chickens at Kunto Dewo farm included four stages, namely preparation of cages, feeding and drinking, recording, and the last stage of the 
harvesting process. For production costs at the Kunto Dewo broiler chicken farm at Rp. 422,526,612. While the total revenue is $R p .438,641,400$. The results of the calculation of $B E P$ receipts are $R p .114,536,532.26$. the $B E P$ value of production was $6,865.43 \mathrm{Kg}$, while the BEP value was IDR 16,251.02 / Kg, and the broad BEP value was $2416.1 \mathrm{~m} 2$. The calculation of the profit and loss of the Kunto Dewo farm has benefited because the value of receipts, production yields, chicken prices, and area exceeded the value of BEP calculation. Whereas for the $R / C$ Ratio value of 1.038 which means that Kunto Dewo's livestock business benefits because the $R / C$ ratio $>1$. for the calculation of $B / C$ ratio of 3.813 which means that Kunto Dewo livestock business is based on the calculation of $B$ / $C$ Ratio said to be inappropriate because the value of $B$ / $C$ Ratio <from the prevailing bank interest rate, the current bank interest is $4.50 \%$.

Keywords: Business, Broiler Chicken Farm.

\section{PENDAHULUAN}

Sektor perternakan merupakan salah satu sektor penyedia pangan utama untuk menopang pertumbuhan industri. Hingga saat ini sektor perternakan sebagai mesin penggerak pembangunan nasional maupun daerah memegang peranan penting dalam perekonomian masyarakat (Yunus, 2007).

Di era globalisasi pendapatan perkapita penduduk Indonesia semakin meningkat, hal ini seiring dengan meningkatnya kebutuhan akan protein hewani. Masyarakat mulai menyadari tentang pentingnya protein hewani bagi pertumbuhan jaringan tubuh. Salah satu sumber protein hewani terdapat pada ayam broiler. Ayam broiler merupakan salah satu penyumbang terbesar protein hewani, bila ditinjau dari nilai gizinya ayam broiler tidak kalah dibanding dengan daging ternak lainnya (Sholikin, 2011). Harga ayam broiler relatif murah dan mudah didapat, hal tersebut dikarenakan pemeliharaan ayam broiler relatif singkat yaitu antara 35-40 hari.

Tingginya tingkat konsumsi ayam broiler di Indonesia, tidak seimbang dengan kenaikan populasi dan produksi ayam broiler yang dihasilkan. Hal itu disebabkan salah satunya karena manajemen produksi yang belum efisien dan efektif. Salah satu kendala yang dihadapi dalam pemeliharaan ayam broiler adalah harga pakan yang tidak menentu (Solikhin, 2011). Dalam berternak ayam broiler pakan merupakan faktor biaya yang paling penting. Penerapan manajemen produksi pada peternakan rakyat sangat sedikit. Hal tersebut akan menghambat pada peningkatan populasi ayam broiler.

Selain harga pakan yang tidak menentu kendala lain yang dihadapi dalam memelihara ayam adalah keterbatasan pengetahuan peternak dalam memelihara ternaknya. Pengetahuan dasar yang perlu diketahui dalam peternak 
dalam memelihara ayam yaitu pemberian vaksinasi dan komposisi pakan yang harus sesuai dengan umur ternak, waktu dalam pemberian makan ternak sesuai dengan kebutuhan ternak, perawatan dan mengurus kandang untuk menjaga kesehatan ayam dan kebersihan kandang (Dian dkk, 2013).

Pada saat ini pengembangan bidang peternakan semakin menjadi perhatian penting karena adanya program diversifikasi pangan untuk meningkatkan kualitas gizi masyarakat yang mana dalam kaitan ini peternakan merupakan sumber produksi pangan berkualitas tinggi, adanya permintaan konsumsi masyarakat akan produk peternakan masih jauh melebihi persediaan yang ada dan yang terakhir yaitu usaha ternak di pedesaan mampu memberikan tambahan pendapatan dan lapangan pekerjaan bagi keluarga petani dan masyarakat.

Sektor peternakan pernah mengalami penurunan disaat perekonomian Indonesia dilanda krisis moneter dan virus flu burung. Menurut artikel Ilham Patu (2010) dalam Dian dkk. (2013), bahwa di Indonesia virus flu burung (H5N1) tersebut menyerang ternak ayam sejak bulan Oktober 2003 sampai dengan Februari 2005 yang mengakibatkan 14,7 juta ayam mati.
Penyakit ini menimbulkan kematian yang sangat tinggi (hampir $90 \%$ ) pada beberapa peternakan dan menyebabkan kerugian ekonomi yang besar bagi peternak karena minat masyarakat untuk mengkonsumsi hasil peternakan seperti daging ataupun telur ayam menjadi berkurang. Selain itu krisis moneter juga mempengaruhi usaha ternak ayam pedaging, dimana pada masa itu terjadi gejolak harga yang cukup signifikan, sehingga biaya produksi meningkat tajam sementara konsumsi masyarakat semakin menurun dan daya beli masyarakat menjadi semakin terbatas.

Keberlanjutan usaha peternakan ditentukan oleh pengetahuan setiap peternak tentang aspek-aspek kelayakan suatu usaha. Suatu usaha dikatakan layak jika memenuhi syarat-syarat seperti layak pasar dan pemasaran, layak teknis, dan layak finansial (Amrizal, 2011).

Usaha peternakan dapat bertahan jika keuntungan yang diperoleh lebih besar daripada biaya yang dikeluarkan, sehingga dapat dikatakan layak untuk dilanjutkan. Hanya sebagian kecil dari peternakan rakyat yang sudah menerapkan manajemen pemeliharaan yang sesuai dan diikuti dengan penerapan teknologi. Hal tersebut disebabkan kurangnya pengetahuan peternak dalam melakukan 
uji kelayakan usaha sehingga menjadi salah satu hambatan dalam peningkatan populasi ayam broiler. Untuk itu sebelum memulai bisnis atau usaha diperlukan analisis usaha untuk mengetahui sejauhmana usaha layak dijalankan, kapan balik modal akan tercapai dan seberapa besar keuntungan yang didapat. Dari penjelasan latar belakang diatas, maka peneliti tertarik melakukan penelitian lebih lanjut mengenai Ternak Ayam Broiler, dengan judul : "Analisis Usaha Ternak Ayam Broiler (Studi Kasus di Ternak Ayam Kunto Dewo Dusun Damar Desa Sekarmojo)".

\section{KERANGKA PEMIKIRAN}

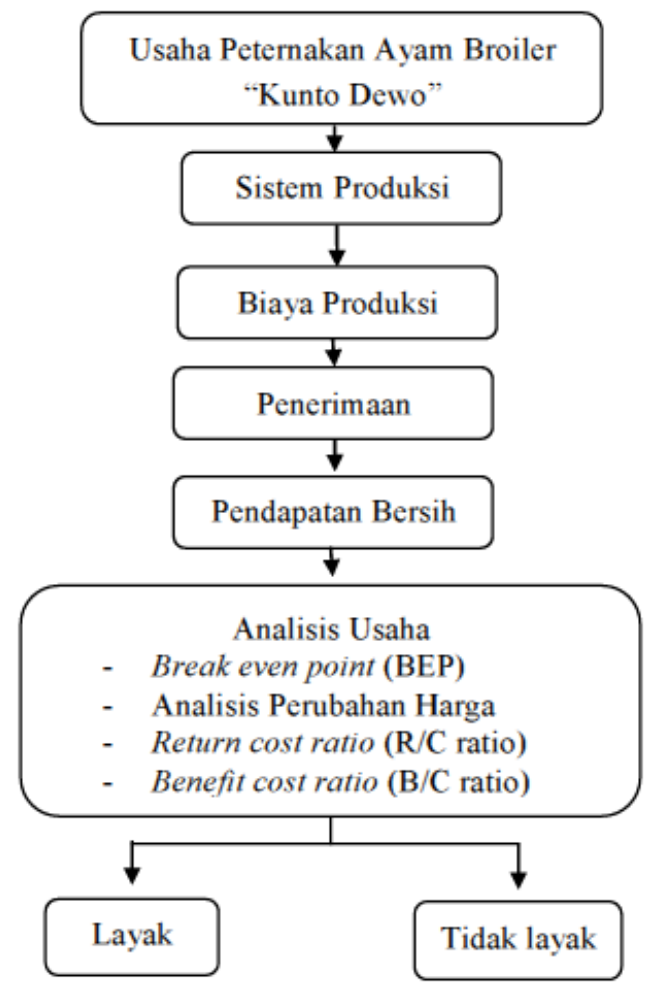

Gambar 2.1 Kerangka Pemikiran Penelitian
Berdasarkan kerangka penelitian di atas, usaha ternak merupakan kegiatan memproduksi di lingkungan peternakan yang pada akhirnya akan dinilai dari biaya yang dikeluarkan dan penerimaan yang diperoleh. Dalam pelaksanaan usaha peternakan pemanfaatan faktor harga secara efisien sebagai salah satu tolak ukur dalam menentukan keuntungan yang diperoleh dari usaha tersebut.

Dalam menjalankan usaha setiap petani berusaha agar produksi dari usahanya tinggi. Untuk mendapatkan hasil produksi yang tinggi sesuai yang diharapkan diperlukan faktor-faktor produksi. Faktor produksi merupakan input produksi seperti lahan, modal, tenaga kerja, dan sarana produksi yang akan mnejadi komponen biaya produksi. Besarnya masing-masing komponen biaya tersebut dipengaruhi oleh jumlah input yang digunakan pada masing-masing input dengan akhirnya secara bersamasama akan mempengaruhi besarnya total biaya produksi.

Dalam suatu usaha dibutuhkan biaya untuk memperoleh produksi yang maksimal. Semua pengeluaran yang dikeluarkan dalam usaha dimasukkan dalam biaya produksi. Adapun biaya produksi meliputi biaya tetap dan biaya variabel. 
Kemajuan suatu usaha diukur dari tingkat produktivitasnya. Dikatakan produkstif jika hasil produktivitasnya tinggi. Untuk mencapai tingkat produktivitas yang tinggi maka hasil produksi harus besar. Produktivitas suatu usaha dapat diketahui dari banyaknya hasil produksi yang diperoleh dari satu kesatuan input. Untuk memperoleh penerimaan usaha dilihat dari hasil penjualan produksinya. Penerimaan usaha merupakan hasil perkalian antara produksi usaha dengan harga jual pada saat itu yang dinilai dengan rupiah, untuk mengetahui pendapatan bersih maka perlu diketahui biaya produksi. Pendapatan bersih diperoleh dari hasil pengurangan antara penerimaan dengan biaya produksi. Sedangkan untuk mengetahui layak tidaknya suatu usaha dalam penelitian ini dapat diketahui melalui analisis BEP, analisis perubahan harga, $\mathrm{R} / \mathrm{C}$ ratio, dan $\mathrm{B} / \mathrm{C}$ ratio.

\section{METODE PENELITIAN}

Metode analisis data yang digunakan yaitu kuantitatif. Penelitan ini akan dilakukan di peternakan ayam broiler Kunto Dewo yang terletak di Dusun Damar Desa Sekarmojo Kecamatan Purwosari Kabupaten Pasuruan. Teknik pengumpulan data dalam penelitian ini melalui beberapa cara yaitu Observasi, Dokumentasi, dan Interview.

Untuk mengetahui total biaya produksi dapat dihitung dengan rumus :

$$
\mathrm{TC}=\mathrm{FC}+\mathrm{VC}
$$

Dimana :

$\mathrm{TC}=$ Total Cost $/$ Total Biaya

$\mathrm{FC}=$ Fixed Cost $/$ Biaya Tetap

$\mathrm{VC}=$ Variable Cost/Biaya Variabel

Untuk mengetahui penerimaan usaha ternak ayam broiler dapat dihitung dengan rumus:

$$
\mathbf{R}=\mathbf{Y} \text {. } \mathbf{P}
$$

Dimana :

$\mathrm{R}$ = Total Revenue/Total Penerimaan

$\mathrm{Y}=$ Total Produksi

$\mathrm{P}=$ Harga Produksi

Untuk mengetahui pendapatan bersih dapat dihitung dengan cara menghitung selisih penerimaan yang diterima dengan total biaya yang dikeluarkan (Soekartawi, 2002), yaitu:

$$
\mathbf{I}=\mathbf{R}-\mathrm{TC}
$$

Dimana :

I $=$ Pendapatan

$\mathrm{R}=$ Total Penerimaan

$\mathrm{TC}=$ Total Cost/Total Biaya

Untuk mengetahui analisis usaha di peternakan Kunto Dewo peneliti 
menggunakan perhitungan Break even point (BEP), analisis perubahan harga, Return cost ratio (R/C ratio) dan Benefit cost ratio ( $\mathrm{B} / \mathrm{C}$ ratio), adapun rumusnya sebagai berikut:

\section{Break even point (BEP)}
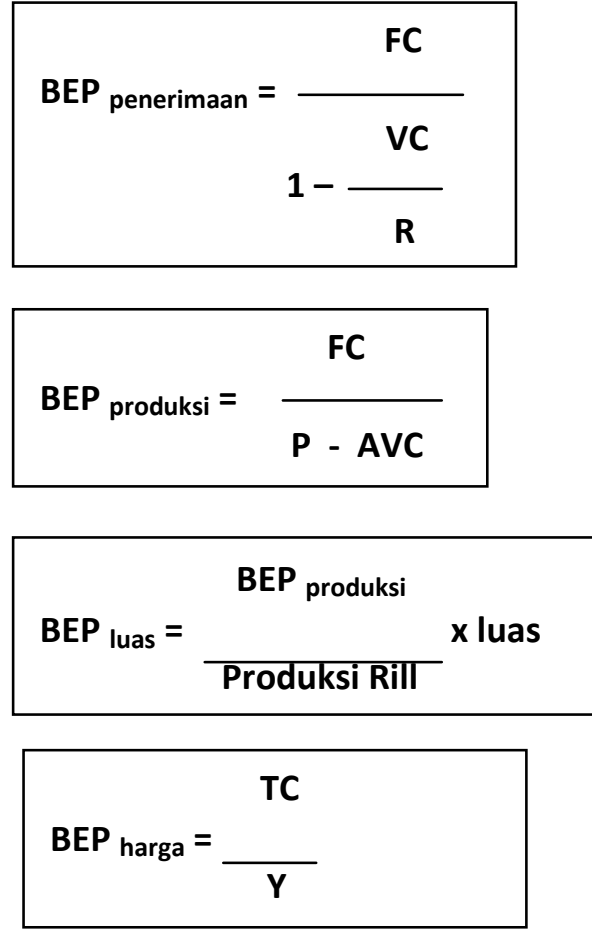

Dimana :

FC = Biaya tetap

$\mathrm{TC}$

$$
=\text { Total Cost/Total Biaya }
$$

$\mathrm{VC}$

$$
\text { = Biaya variabel }
$$

AVC

$$
\text { = Biaya variabel per unit }
$$

$\mathrm{Y}$

$$
=\text { Total produksi }
$$

Produksi Rill $=$ Hasil produksi saat penelitian

(Suratiyah, 2015)

2. Analisis Perubahan Harga

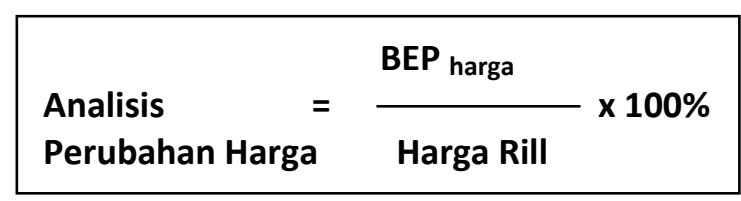

Dimana : Harga Rill = Harga saat penelitian

(Suratiyah, 2015)

\section{Return cost ratio ( $\mathrm{R} / \mathrm{C}$ ratio)}

$$
\mathrm{R} / \mathrm{C}_{\text {ratio }}=\frac{\mathrm{R}}{\mathrm{TC}}
$$

Dimana :

$\mathrm{R} / \mathrm{C}_{\text {ratio }}=$ Return cost ratio

$\mathrm{R}=$ Total penerimaan

$\mathrm{TC}=$ Total Cost/Total Biaya

Jika nilai $\mathrm{R} / \mathrm{C}$ ratio $>1$ maka usaha dikatakan layak, namun jika nilai BCR $<1$ maka usaha dikatakan tidak layak (Suratiyah, 2015).

4. Benefit cost ratio (B/C ratio)

$$
\mathrm{B} / \mathrm{C}_{\text {ratio }}=\frac{\pi}{\mathrm{TC}} \times 100 \%
$$

Dimana :

$\mathrm{B} / \mathrm{C}_{\text {ratio }}=$ Benefit cost ratio

$$
\begin{aligned}
\boldsymbol{\pi}= & \text { Keuntungan } \\
& \text { dikurangi upah tenaga kerja } \\
& \text { keluarga) } \\
\mathrm{TC}= & \text { Total biaya }
\end{aligned}
$$

Jika nilai $\mathrm{BCR}>$ bunga bank yang berlaku maka usaha dikatakan layak, namun jika nilai BCR < bunga bank yang 
berlaku maka usaha dikatakan tidak layak (Suratiyah, 2015).

\section{HASIL PENELITIAN}

Hasil penelitian menunjukkan sistem produksi usaha ayam broiler di peternakan Kunto Dewo meliputi empat tahap yaitu persiapan kandang, pemberian pakan dan minum, pencatatan, dan tahap terakhir proses pemanenan.

\section{Biaya Produksi}

Untuk Biaya produksi pada peternakan ayam broiler Kunto Dewo sebesar $\mathrm{Rp}$ 422,526,612, dengan rincian sebagai berikut:

Tabel 1 Biaya Total (Total Cost)

\begin{tabular}{|l|l|l|}
\hline No & Jenis Biaya & Total $(\mathbf{R p})$ \\
\hline 1 & $\begin{array}{l}\text { Biaya } \\
\text { Penyusutan/ } \\
\text { Periode }\end{array}$ & Rp 4,567,956 \\
\hline 2 & $\begin{array}{l}\text { Biaya Tetap/ } \\
\text { Periode }\end{array}$ & Rp $1,113,056$ \\
\hline 3 & $\begin{array}{l}\text { Biaya } \\
\text { Variabel/ } \\
\text { Periode }\end{array}$ & Rp 416,845,600 \\
\hline \multicolumn{2}{|c|}{ Total Cost (TC) } & Rp 422,526,612 \\
\hline
\end{tabular}

Sumber: Data Diolah

Dari tabel $1 \mathrm{di}$ atas jumlah total cost (biaya total) sebesar $\operatorname{Rp} 422,526,612$ dengan rincian biaya penyusutan sebesar Rp 4,567,956,-/periode sedangkan untuk biaya tetap sebesar Rp 1,113,056/periode. Untuk biaya Variabel/Periode menghabiskan biaya sebesar Rp $416,845,600,-$.

\section{Penerimaan dan Pendapatan Bersih}

Tabel 2 Penerimaan

\begin{tabular}{|l|l|l|}
\hline No. & Nama Barang & $\begin{array}{l}\text { Jumlah } \\
\text { Penerimaan }\end{array}$ \\
\hline 1 & Ayam & Rp 438,360,000 \\
\hline 2 & Kotoran & Rp 281,400 \\
\hline \multicolumn{2}{|c|}{ Total Penerimaan (R) } & Rp 438,641,400 \\
\hline
\end{tabular}

Sumber: Data Diolah

Berdasarkan tabel 2 di atas dapat dilihat bahwa total penerimaan (R) sebesar Rp 438,641,400,- dengan rincian penerimaan dari penjualan ayam sebesar Rp 438,360,000,- dan ditambah penerimaan hasil penjualan kotoran ayam sebesar Rp 281,400,-.

\section{Tabel 3 Pendapatan Bersih}

\begin{tabular}{|l|l|l|}
\hline $\begin{array}{l}\text { Total } \\
\text { Penerimaan } \\
\text { (R) }\end{array}$ & $\begin{array}{l}\text { Total Cost } \\
\text { (TC) }\end{array}$ & $\begin{array}{l}\text { Pendapatan } \\
\text { Bersih (Pd) }\end{array}$ \\
\hline $38,641,400$ & $422,526,612$ & $\mathbf{1 6 , 1 1 4 , 7 8 8}$ \\
\hline
\end{tabular}

Sumber: Data Diolah

Berdasarkan tabel 3 di atas dapat dilihat bahwa pendapatan bersih peternakan ayam broiler Kunto dewo sebesar Rp 16,114,788, hasil perhitungan pendapatan tersebut hasil perselisihan (pembagian) antara total penerimaan sebesar Rp 438,641,400,- dan Total cost (biaya total) sebesar $\mathrm{Rp} 422,526,612$.

\section{Analisis Usaha}


Untuk menganalisis usaha impas pada saat luas peternakan sebesar peternakan ayam Kunto Dewo dapat $2416,1 \mathrm{~m}^{2}$.

diketahui dengan menggunakan analisis $\mathrm{BEP}$, Analisis perubahan harga, $\mathrm{R} / \mathrm{C}$ ratio dan $\mathrm{B} / \mathrm{C}$ ratio. Berikut tabel hasil perhitungan BEP, Analisis perubahan harga, $\mathrm{R} / \mathrm{C}$ ratio dan $\mathrm{B} / \mathrm{C}$ ratio, sebagai berikut:

\section{Tabel 5 Analisis Perubahan Harga}

\begin{tabular}{|l|l|l|l|}
\hline $\begin{array}{l}\text { Harga } \\
\text { Produk (p) } \\
\text { saat } \\
\begin{array}{l}\text { Penelitian } \\
(\mathbf{R p})\end{array}\end{array}$ & $\begin{array}{l}\text { Harga } \\
\text { Produk } \\
\text { (p) saat } \\
\text { BEP } \\
\text { (Rp) }\end{array}$ & $\begin{array}{l}\text { Harga } \\
\text { saat BEP } \\
\text { dari } \\
\text { Harga riil } \\
\text { saat } \\
\text { penelitian }\end{array}$ & $\begin{array}{l}\text { Analisis } \\
\text { Peruba } \\
\text { han } \\
\text { Harga }\end{array}$ \\
\hline 16.860 & $16.251,0$ & $96,38 \%$ & $3,62 \%$ \\
\hline
\end{tabular}

Sumber: Data Diolah

Dari tabel 5 di atas dapat dilihat Tabel 4 BEP (Break Even Point)

\begin{tabular}{|l|l|l|}
\hline $\begin{array}{l}\text { Analisis } \\
\text { BEP }\end{array}$ & Hasil BEP & $\begin{array}{l}\text { Kondisi } \\
\text { Saat ini }\end{array}$ \\
\hline $\begin{array}{l}\mathrm{BEP} \\
\text { penerimaan }\end{array}$ & $114.536 .532,26$ & 438.641 .400 \\
\hline $\begin{array}{l}\mathrm{BEP} \\
\text { produksi }\end{array}$ & $6.865,43 \mathrm{Kg}$ & $26.000 \mathrm{Kg}$ \\
\hline BEP $_{\text {harga }}$ & $16.251,02 / \mathrm{Kg}$ & $16.860 / \mathrm{Kg}$ \\
\hline $\mathrm{BEP}_{\text {luas }}$ & $2416,1 \mathrm{~m}^{2}$ & $9150 \mathrm{~m}^{2}$ \\
\hline
\end{tabular}

bahwa titik impas presentase perubahan harga sebesar 3,62\%, yang artinya jika peternakan Kunto Dewo mengalami penurunan harga kurang dari 3,62\% Maka peternakan Kunto Dewo tidak rugi atau mengalami keuntungan. Akan tetapi

Sumber: Data Diolah

Berdasarkan tabel 4 di atas dapat dilihat bahwa nilai BEP penerimaan sebesar Rp. 114.536.532,26 yang artinya peternakan Kunto Dewo mengalami titik impas pada saat penerimaan sebesar Rp. 114.536.532,26. Untuk nilai BEP produksi sebesar 6.865,43 Kg yang berarti peternakan Kunto Dewo mengalami titik impas pada saat produksi sebesar 6.865,43 Kg. Sedangkan BEP harga Rp 16.251,02/ Kg yang artinnya peternakan Kunto dewo mengalami titik impas pada saat harga jual sebesar Rp 16.251,02/ Kg. Nilai BEP luas sebesar 2416,1 $\mathrm{m}^{2}$ yang berarti bahwa peternakan Kunto Dewo mengalami titik sebaliknya jika peternakan Kunto Dewo mengalami penurunan harga lebih dari 3,62\% Maka peternakan Kunto Dewo mengalami kerugian.

\section{Tabel $6 \mathrm{R} / \mathrm{C}$ ratio}

\begin{tabular}{|l|l|l|}
\hline $\begin{array}{l}\text { Total } \\
\text { Penerimaan } \\
(\mathbf{R})\end{array}$ & $\begin{array}{l}\text { Total Cost } \\
(\text { TC })\end{array}$ & $\begin{array}{l}\text { R/C } \\
\text { Ratio }\end{array}$ \\
\hline $\operatorname{Rp~} 438,641,400$ & $\operatorname{Rp~422,526,612~}$ & $\mathbf{1 . 0 3 8}$ \\
\hline
\end{tabular}

Sumber: Data Diolah

Berdasarkan tabel 6 di atas bahwa nilai R/C Ratio sebesar 1.038 yang artinya bahwa usaha peternakan Kunto Dewo berdasarkan hasil perhitungan R/C Ratio layak dijalankan, karena dikatakan layak jika nilai $\mathrm{R} / \mathrm{C}$ ratio $>1$.

\section{Tabel 7 B/C ratio}

\begin{tabular}{|c|l|c|}
\hline $\begin{array}{c}\text { Keuntungan } \\
(\pi)\end{array}$ & Total Cost $(T C)$ & $\begin{array}{c}\text { B/C } \\
\text { Ratio }\end{array}$ \\
\hline
\end{tabular}




\section{\begin{tabular}{l|l|l} 
Rp 16,144,788 & Rp 422,526,612 & $\mathbf{3 , 8 1 3}$
\end{tabular}}

Sumber: Data Diolah

Berdasarkan tabel 7 di atas bahwa nilai

B/C Ratio sebesar 3,813 yang artinya bahwa usaha peternakan Kunto Dewo berdasarkan hasil perhitungan B/C Ratio dikatakan tidak layak karena nilai B/C Ratio < dari bunga bank yang berlaku, bunga bank yang berlaku saat ini adalah $4,50 \%$.

\section{KESIMPULAN}

Berdasarkan hasil penelitian di atas, maka dapat diperoleh kesimpulan sebagai berikut:

1. Sistem produksi usahatani ayam broiler di peternakan Kunto Dewo meliputi empat tahap, yang pertama persiapan kandang, proses persiapan kandang terdiri dari proses pencucian dan sterilisasi, menyiapkan pemanas, memasang tempat pakan dan tempat minum, pemasangan tirai, pemasukan DOC (day old chick). Tahap kedua pemberian pakan dan minum, tahap ketiga pencatatan, dan tahap terakhir proses pemanenan.

2. Biaya produksi pada peternakan ayam broiler Kunto Dewo terdiri dari Biaya tetap, biaya variabel, biaya penyusutan peralatan dan kandang. Jadi jumlah total cost (biaya total) produksi peternakan Kunto Dewo sebesar Rp $422,526,612$.
3. Total penerimaan (R) sebesar $\mathrm{Rp}$ 438,641,400,- dengan rincian penerimaan dari penjualan ayam sebesar Rp 438,360,000,- dan ditambah penerimaan hasil penjualan kotoran ayam sebesar Rp 281,400,-. Sedangkan untuk pendapatan bersih peternakan ayam broiler Kunto dewo sebesar Rp $16,144,788$.

4. Analisis usaha pada penelitian ini menggunakan analisis BEP, analisis perubahan harga, $\mathrm{R} / \mathrm{C}$ ratio dan $\mathrm{B} / \mathrm{C}$ ratio. Hasil perhitungan BEP penerimaan sebesar Rp. 201.487.658,32 yang artinya peternakan Kunto Dewo mengalami titik impas pada saat penerimaan $\mathrm{Rp}$. 201.487.658,32. Untuk nilai BEP produksi sebesar $12.051,94 \mathrm{Kg}$ artinya peternakan Kunto Dewo mengalami titik impas pada saat produksi sebesar 12.051,94 Kg. Nilai BEP harga Rp 16.251,02/ Kg, artinya peternakan Kunto Dewo mengalami titik impas pada saat harga jual ayam seharga 16.251,02/ Kg. Nilai BEP luas sebesar 4241,35 $\mathrm{m}^{2}$ artinya peternakan Kunto Dewo mengalami titik impas pada saat luas sebesar 4241,35 $\mathrm{m}^{2}$. Sedangkan untuk analisis perubahan harga diperoleh titik impas sebesar 3,62\%, yang artinya jika peternakan Kunto 
Dewo mengalami penurunan harga

kurang dari 3,62\% Maka peternakan

Kunto Dewo tidak rugi atau mengalami keuntungan begitupun sebaliknya.

Untuk nilai R/C Ratio sebesar 1.038 yang artinya bahwa usaha peternakan Kunto Dewo layak dijalankan, karena nilai $\mathrm{R} / \mathrm{C}$ ratio > 1 . Sedangkan untuk hasil perhitungan B/C Ratio sebesar 3,813 dan dikatakan tidak layak karena nilai BCR < bunga bank yang berlaku.

\section{DAFTAR PUSTAKA}

Amrizal, 2011. Analisis Finansial Usaha Peternakan Ayam Broiler di Peternakan Karisa Kelurahan Simpang Baru Kecamatan Tampan Kota Pekanbaru. Skripsi. Program Studi Peternakan, Fakultas Pertanian dan Peternakan, Universitas
Islam Negeri Sultan Syarif Kasim Riau.

Dian, Krisno A. Richo., 2013. Kelayakan Usaha Budidaya Ayam (Analisis Biaya Manfaat dan BEP pada Keanu Farm, Kendal). Skripsi. Program Studi Ekonomi Pembangunan, Fakultas Ekonomi, Universitas Negeri Semarang.

Solikhin, 2011. Manajemen Ayam Broiler di Peternakan UD. Hadi PS Kecamatan Nguter Kabupaten Sukaharjo. Tugas Akhir, Program Diploma III Agibisnis Peternakan, Fakultas Pertanian, Universitas Sebelas Maret Surakarta.

Suratiyah, Ken., 2015. Ilmu Usahatani. Penebar Swadaya, Jakarta.

Yunus, Muhammad., 2007. Analisis Usaha Peternakan Ayam Broiler (Studi Kasus pada Usaha Peternakan Ayam Broiler di Kelurahan Borongloe, Kecamatan Bontomarannu, Kabupaten Gowa). Jurnal Agrosistem. 